\title{
Design of Photovoltaic System Using Buck-Boost Converter based on MPPT with PID Controller
}

\author{
Osama Elbaksawi ${ }^{1,2}$ \\ ${ }^{1}$ Department of Electrical Engineering , College of Engineering, Jouf University, Sakaka, Kingdom of Saudi Arabia \\ ${ }^{2}$ Department of Electrical Engineering , Faculty of Engineering, Port-said University, Egypt.
}

Received September 15, 2019; Revised October 30, 2019; Accepted November 10, 2019

Copyright $\bigcirc 2019$ by authors, all rights reserved. Authors agree that this article remains permanently open access under the terms of the Creative Commons Attribution License 4.0 International License

\begin{abstract}
Different models of the PV system containing many techniques of DC-DC converter are applied in this paper such as, buck converter, boost converter and buck- boost converter which are inserted to be close the power between PV array and load by varying its duty cycle, it is named maximum power point tracking (MPPT). This paper introduces four different techniques of the DC-DC converter controlled by MPPT. The first configuration is proposed as composing PV module connected to buck-boost converter controlled via incremental conductance MPPT algorithm, the system includes PID controller to reduce the error of output voltage. The second model is as the first without PID controller. The last two systems consisting of boost converter with MPPT control and with PWM technique. All studied methods are pretended by using Matlab/Simulink.
\end{abstract}

Keywords PV system, DC-DC Converter, PID Controller, MPPT Algorithm

\section{Introduction}

Renewable energy sources are the most widely studied electric power sources like wind turbine and photovoltaic cells which are the most popular renewable sources. The photovoltaic model gains a great attention in the last decades as it has not a moving part and produces less pollution to environment. The output characteristic of PV array depends on parameters radiation intensity and temperature [1,2]. Increasing the temperature is decreasing the power generated by PV module at MPP. While, an increase in radiation intensity can cause increasing in the generated power in the maximum power point of PV module [3,4].

The PV cells operate with maximum output power and tracks the maximum available output power of PV array and make PV system more efficient. The MPPT algorithm adopt criteria $\mathrm{dv} / \mathrm{dt}=0$ at maximum points to extract the maximum power. Many different techniques are implemented based on MPPT, which are different in their efficiency, speed response, implementation, cost and popularity [3,5,6]. Different algorithms like conductance are applied to the MPP tracking to control the duty cycle of the converter [7].

\section{Equivalent Circuit of PV Module}

The equivalent circuit of PV general model composes photon current source in parallel with a diode and shunt resistance, all in series with a series resistor. The equivalent circuit is shown as in Figure. 1 [4,8,9].

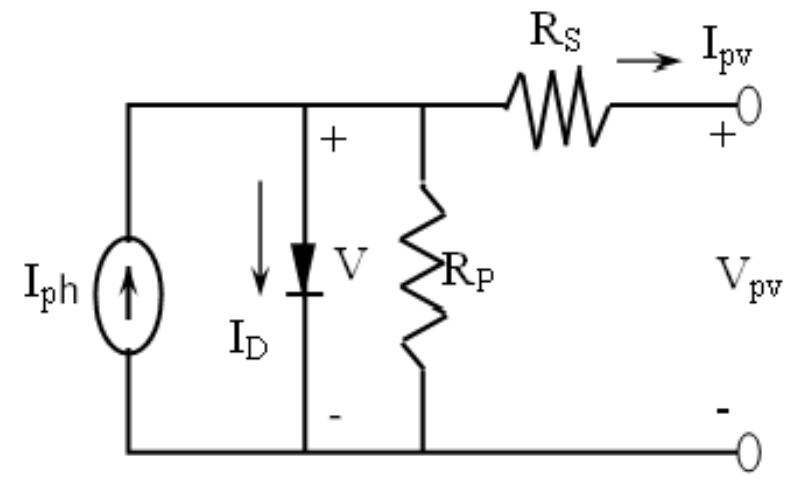

Figure. 1. The equivalent circuit of PV module

$$
I_{P V}=N_{p} I_{P h}-N_{p} I_{o}\left[e^{\frac{V_{P V}+I_{P V} R_{S}}{N_{S} V_{t h}}}-1\right]-\frac{V_{P V}+R_{S} I_{P V}}{R_{p}}
$$

$\mathrm{I}_{\mathrm{ph}}$ : light generated current, Is: panel saturation current, Ns: number of cells connected in series, $\mathrm{Np}$ : number of cells connected parallel, T: cell working temperature , A: ideal factor, Rp: shunt resistance and Rs: series resistance. 


\section{DC-DC Converter Based on MPPT}

DC-DC converter was a vital part of alternative and renewable energy conversion, portable devices, and much industrial process. It is essentially used to achieve a regular DC voltage from DC source with may be the rectifier output or a battery or a solar cell and fed to DC-DC converter [10].

\subsection{Perturb and Observe (P\&O) MPPT Algorithm}

The P \&O method is most used in MPPT because of its simple technique and it requires only few parameters. It perturbs the terminal voltage of PV array and compares the generated output power of $\mathrm{PV}$ with the last cycle of perturbation. When generated power of PV and voltage is increased or decreased, a perturbation step size, the system is oscillating toward the MPP and this oscillation is minimized and the step size perturbation is reducing and it slows down the MPP tracking system. This MPPT algorithm is introduced to provide gate pulses to the MOSFET switch used in the boost converter $[10,11,12]$.

\subsection{PV System Boost Converter with PWM}

The block diagram is introducing the technique of the feed forward control is shown in Figure. 2. It composes of a Solar panel, boost converter, MPPT and a lighting load. The current - voltage characteristics of this panel is tested initially before connecting it to the load $[11,13]$.

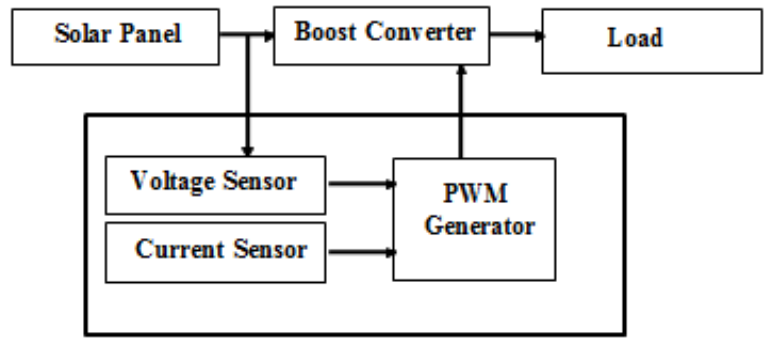

Figure. 2. Block diagram of PV system PWM control technique

\subsection{PV System Boost Converter with MPPT}

A DC-DC boost converter is used to convert the input dc voltage value to the different dc voltage value at the output. The circuit diagram of the boost converter. It consists of an electronic switch which is controlled by PWM signal. The inductor is storing energy from the panel until Ton period when the electronic switch is switched on. Meanwhile, when diode is in the reverse biased it isolates the output from the circuit and the load current supplies from the capacitor. When the electronic switch is switched off, the inductor is discharging and the current flows through the diode.. The output voltage composes of the discharged voltage and instant panel voltage; hence it is always higher than the input voltage. The ON and OFF of the switch is controlled by the PWM signal $[10,11,14]$.

\subsection{PV System Buck-Boost Converter with MPPT}

Buck-Boost converter is collection of a buck and boost converter. It is a combination of the buck converter case and a boost converter case in cascade. The ratio for the output to input voltage is equal to a product of ratios in buck converter and the boost converter. [11,12,15]. The block diagram presenting the technique of the PV system buck-boost converter with MPPT technique is shown in Figure 3.

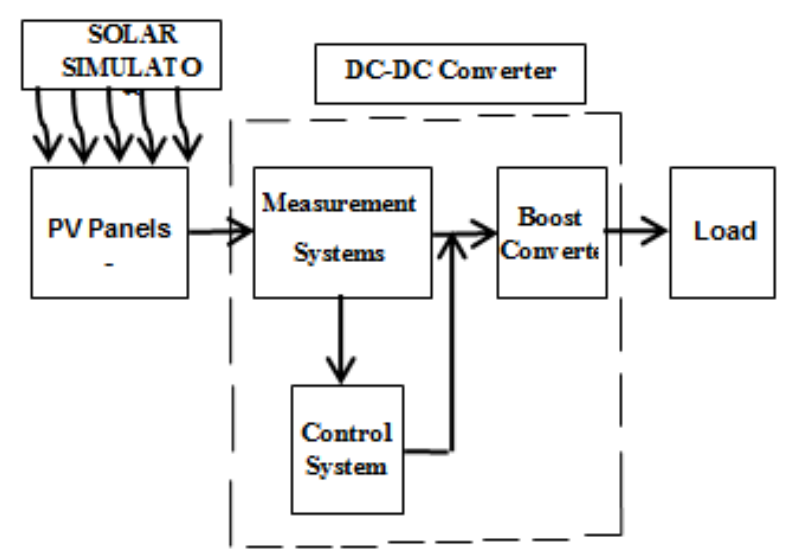

Figure. 3. The block diagram of PV system with DC-DC Converter

\subsection{Incremental Conductance Algorithm for MPPT}

The output power of the solar PV module changes with varies in direction of the sun, change in solar insulations level and vary in temperature. There is a single MPP in the PV characteristics of the PV module for normal operating condition. It is desired the PV module to operate around to this point, i.e., output of the PV module reaches near to MPP. The process of operating PV module at this condition is named as maximum power point tracking (MPPT). Maximization of PV power is improved from the utilization of the solar PV module $[8,15]$.

The most common algorithms are the $\mathrm{P} \& \mathrm{O}$ and the IC method. The conductance method presents the advantage of giving high efficiency under varying atmospheric conditions, so it is introduced in the model. This method is depended on the slop of the PV array power curve is zero at the MPP, and is increasing on the left of the MPP and is decreasing on the right side of MPP.

The algorithm of this technique starts by obtaining values of $I(k)$ and $V(k)$ and using former values stored at the end of the cycle, $I(k-I)$ and $V(k-I)$, then the voltage variable is zero and the current variable equals zero so the PV is operating on the MPP $[10,16]$.

When the PV array is not operating at the MPP; thus the varying in the atmospheric Conditions is detected using (dI 
$\neq 0)$. In this case, the control is depending on $\mathrm{dI}$ is positive or negative, if the incremental change in current is positive, the voltage is increased, otherwise is decreased. While the voltage variable is unequal zero, and is comparing $\mathrm{dI} / \mathrm{dV}$ with $\mathrm{I} / \mathrm{V}$.

The configuration of MPPT controller is composed of the inputs for MPPT controller are voltage, current of the $\mathrm{PV}$ module to control the duty cycle of the DC-DC converter.

Therefore, the problem of the maximized output power can be solved effectively using the duty cycle of DC-DC converter as a control variable with perturbation and observation (P\&O) as the following control law [10,11,12]:

$$
\mathrm{D}_{k}=\mathrm{D}_{k-1}+C_{1} \frac{\Delta P_{k-1}}{\Delta D_{k-1}}
$$

$D_{k}$ and $D_{k-1}$ are duty cycle values in $K$ and $K-1$ intervals, respectively. $\Delta \mathrm{P}_{\mathrm{k}-1} / \Delta \mathrm{D}_{\mathrm{k}-1}$ is the power slope of $\mathrm{PV}$ in step $\mathrm{K}-1$ and $\mathrm{C}_{1}$ is the step change $[13,14,17,18,19]$.

\section{The Proposed Model with PID}

The output power from PV module is fed to DC-DC converter by using Incremental Conductance (IC) algorithm MPPT with PID controller to obtain the point of maximum power as shown in Figure. 4. The proposed model depends on the slope of the derivative of the current to the voltage to reach MPP from measurements of the voltage, $\mathrm{V}$, and the current, I, and the algorithm determines the photovoltaic output power and its derivative as in terms of the voltage. The difference between actual voltage signal and generated voltage signal are compared and fed to PID controller to reduce error and generate the duty cycle to operate DC-DC converter.

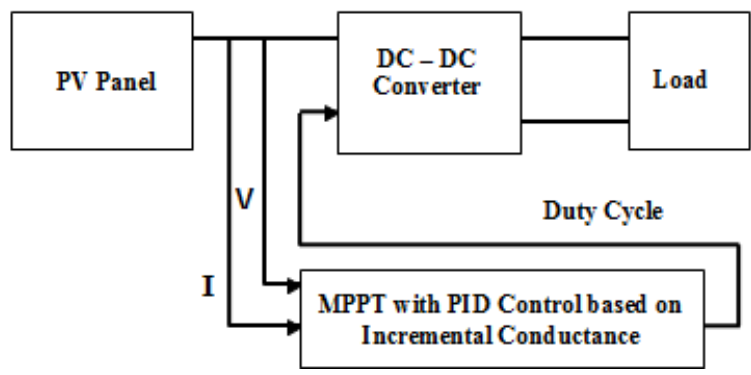

Figure. 4. The block diagram of proposed PV system

The flow chart of the proposed model of MPPT method is implemented in Figure, 5. The operation of this algorithm can be given by the following mathematical equations, $[16,17,18]$

$$
\begin{array}{ll}
\frac{d p}{d v}=0 & \text { At MPP } \\
\frac{d p}{d v}>0 & \text { At the left of MPP } \\
\frac{d p}{d v}<0 & \text { At the right of MPP }
\end{array}
$$

Since,

$$
\begin{array}{cl}
\frac{d p}{d v}=\frac{d(I V)}{d v}=I+V \frac{d I}{d V} \\
\frac{\Delta I}{\Delta V}=\frac{-I}{V} \quad, \text { at MPP } \\
\frac{\Delta I}{\Delta V}>\frac{-I}{V}, & \text { at the left of MPP }
\end{array}
$$

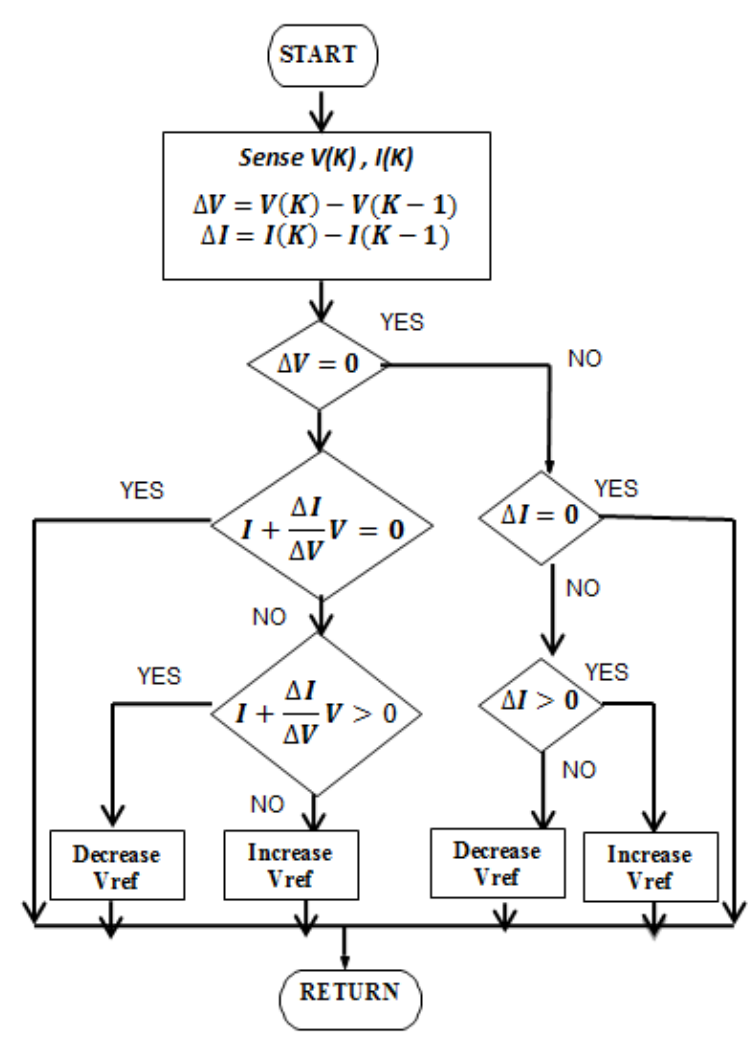

Figure. 5. The flowchart of IC algorithm

\section{Analysis Results}

The proposed PV module is simulated by Matlab/Simulink as shown in Figure. 6 and compared with three others model. The specification of the PV array and optimized ratings are illustrated in Table 1. Figure.7.a and Figure.7.b show the characteristics curve of PV module and PV which it used array. The output voltages, current and power for the proposed model PV system usage buck-boost converter based on MPPT with PID controller are shown in Figure. (8.a, 9.a, 10.a), the PV system usage buck-boost converter based on MPPT controller is shown in Figure. (8.b, 9.b, 10.b), while the PV system usage boost converter based on MPPT are shown in Figure. (8.c, 9.c, 10.c) and PV system usage boost converter based on PWM are shown in Figure. (8.d, 9.d, 10.d) 
It is illustrated from Figure. 8.a to Figure. 8.d which are shown the wave form of output and input voltage for the proposed technique are the best wave because it has a low harmonics and has a high value of the output voltage when is comparing with the other three techniques.

Also, from Figure. 9.a to Figure. 9.d which are shown the wave form of output ant input current of all four techniques ant it clears the wave of the proposed model has no ripple and output current is not excesses the range of PV array maximum current.
While, from Figure. 10.a to Figure. 10.d are presented the output and input power and it is concentrated of wave form from $0.8 \mathrm{sec}$ to $0.805 \mathrm{sec}$ to show the ripple in the each wave for each technique, thus the wave form of the proposed model has a low ripple with less oscillation value about 1.7 watt and the best wave compared with the other techniques.

The comparison simulation results such as output power $(\mathrm{Po})$, ripple in output power $(\Delta \mathrm{Po})$, output voltage $(\mathrm{Vo})$ are in Table 2.

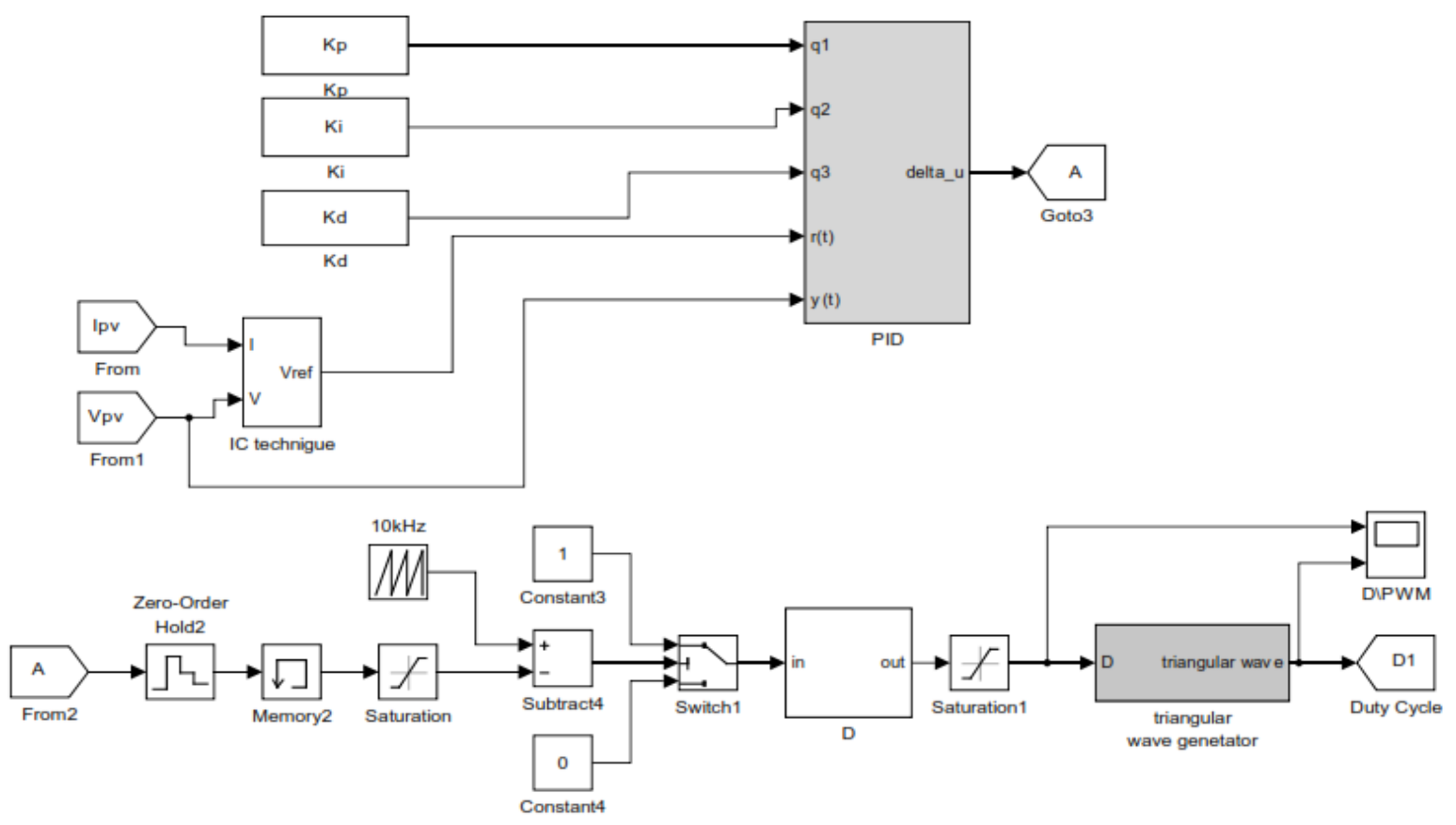

Figure 6. Simulink model of proposed control model

Table 1. Specification of PV array and ratings

\begin{tabular}{|c|c|}
\hline \multicolumn{2}{|c|}{ Electrical specifications of PV array } \\
\hline Module type & First Solar FS - 272 \\
\hline Ns & 3 \\
\hline Np & 3 \\
\hline Maximum power(W) & 680 \\
\hline Voltage at max. power (V) & 37.3 \\
\hline Current at max. power (A) & 8.31 \\
\hline Open circuit voltage (V) & 45.22 \\
\hline Short circuit current (A) & 8.9 \\
\hline Cell temperature, in deg.C. & 25 \\
\hline Sun irradiance, in W/m2 & 1000 \\
\hline
\end{tabular}



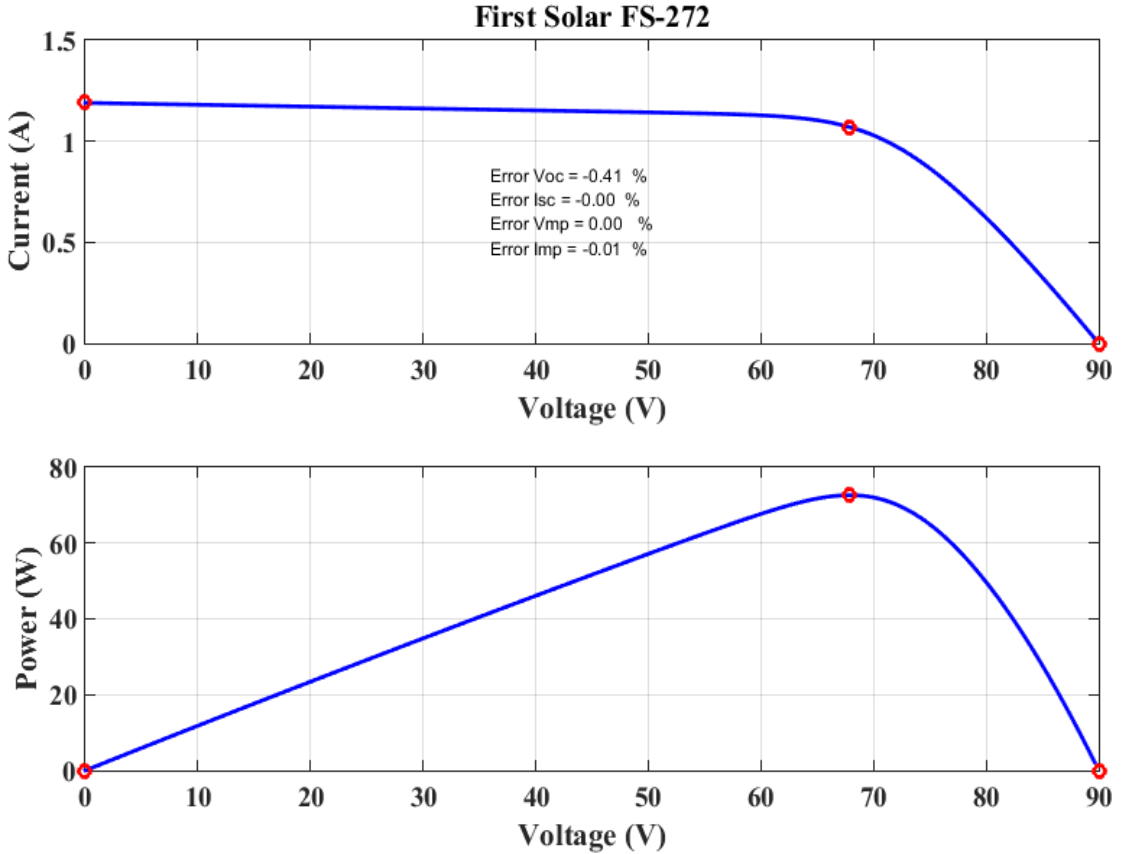

Figure 7a. PV module characteristics

Array type: First Solar FS-272;

3 series modules; 3 parallel strings
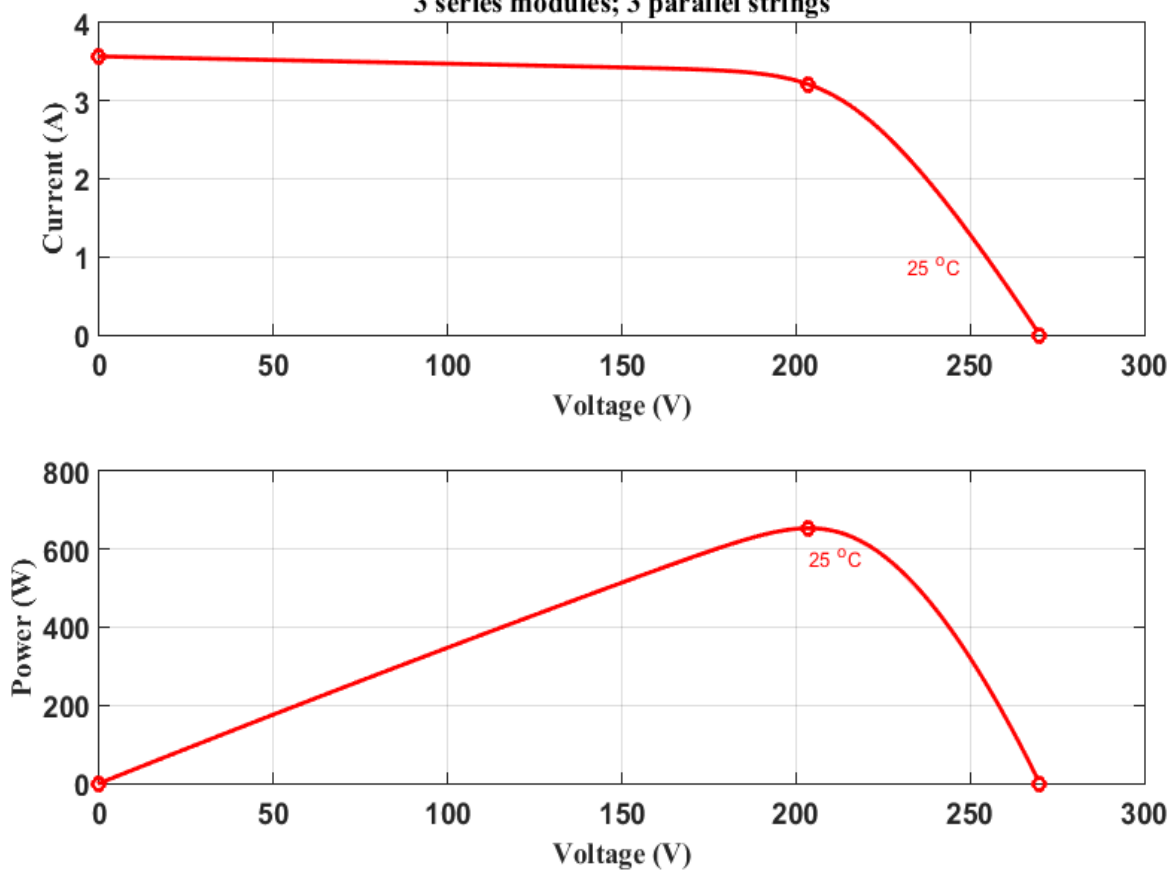

Figure 7b. PV array characteristics 


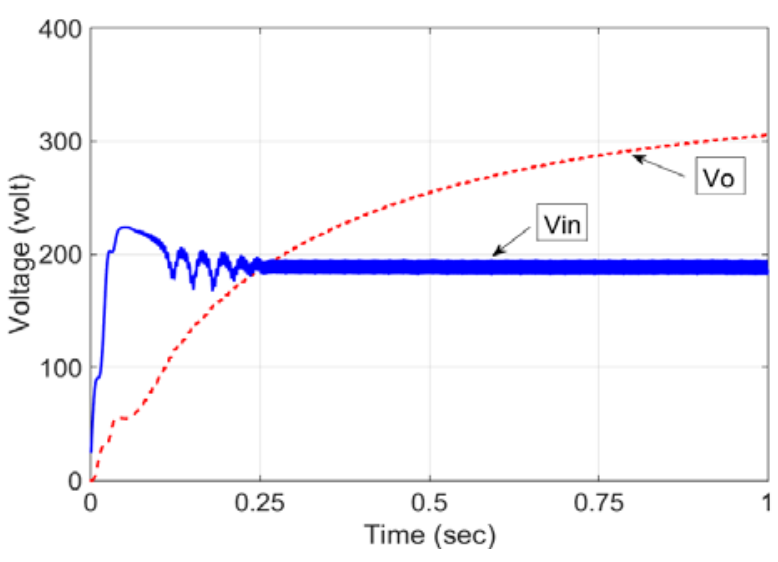

Figure 8a. Vo \& Vin for PV system boost converter PWM

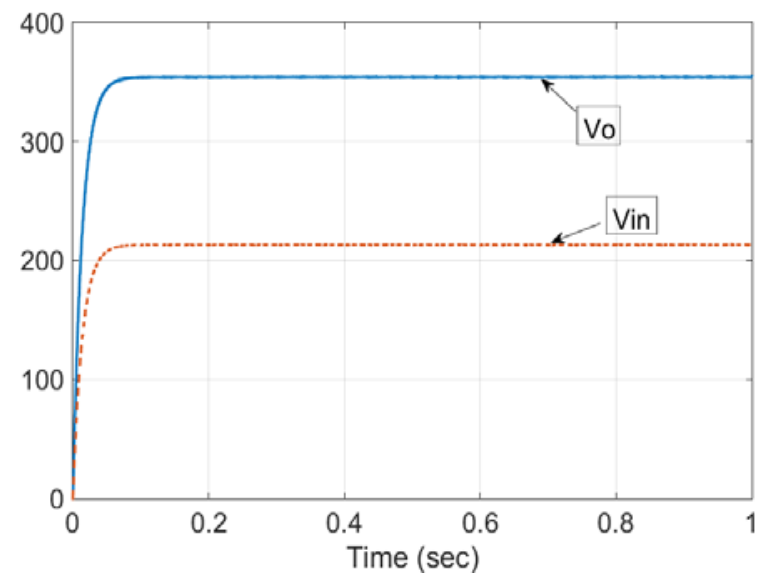

Figure 8b. Vo\&Vin for PV system boost converter MPPT

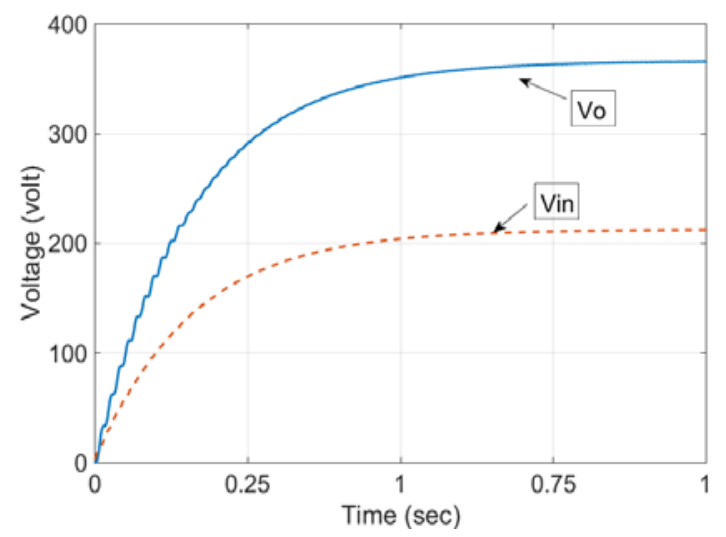

Figure 8c. Vo\&Vin for PV system buck-boost converter with MPPT

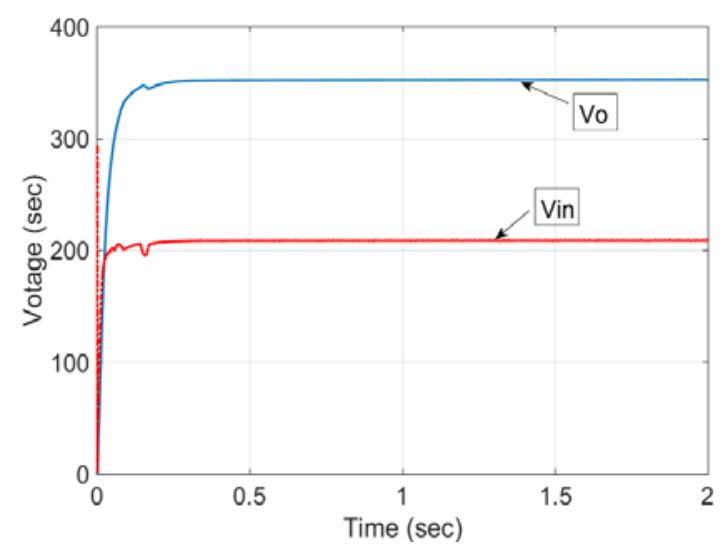

Figure 8d. Vo\&Vin for PV system buck-boost converter PID- MPPT

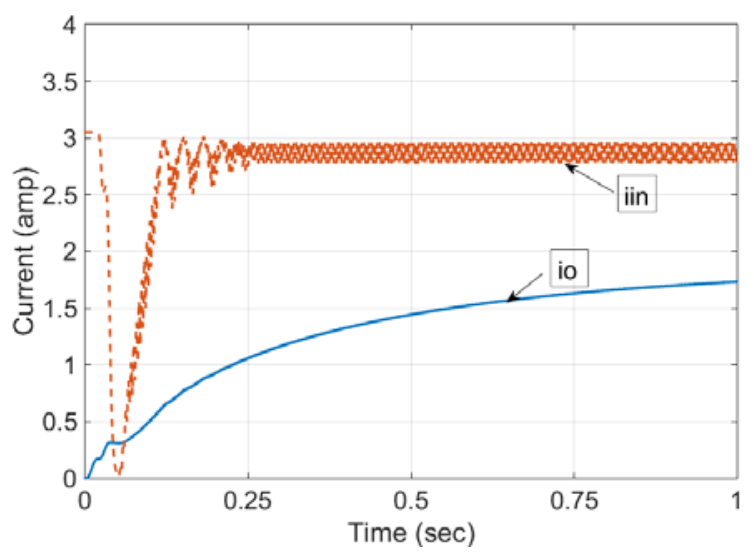

Figure 9a. Io \& Iin for PV system boost converter with PWM

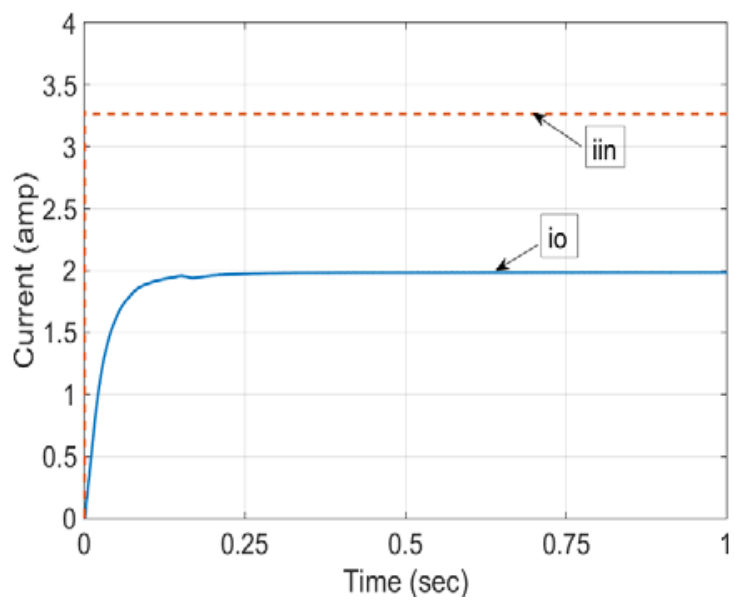

Figure 9b. Io\&Iin for PV system boost converter with MPPT 


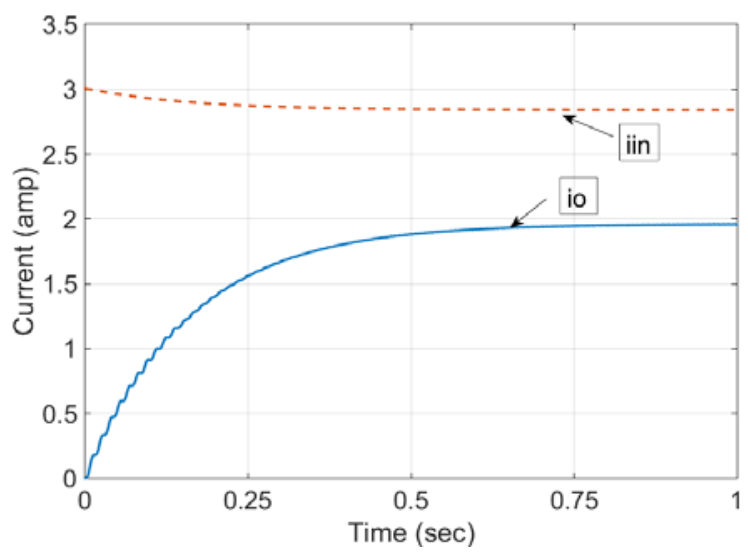

Figure 9c. Po for PV system buck-boost converter with MPPT

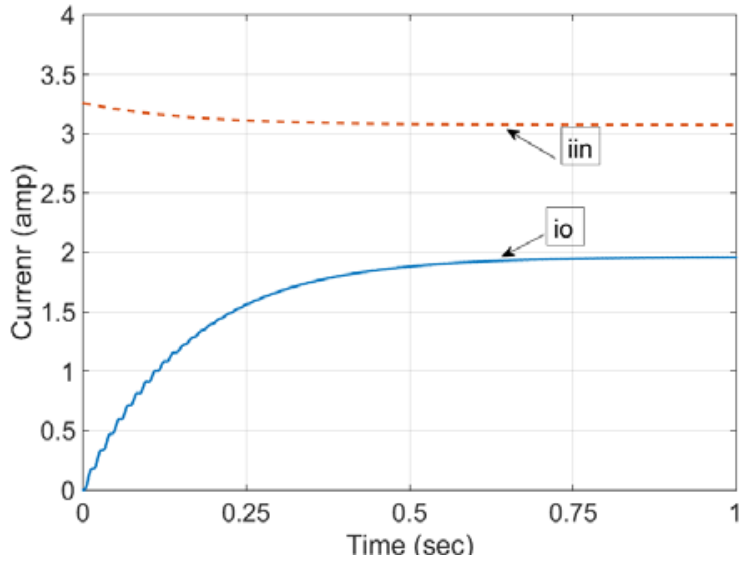

Figure 9d. Po for PV system buck-boost converter with PID-MPPT

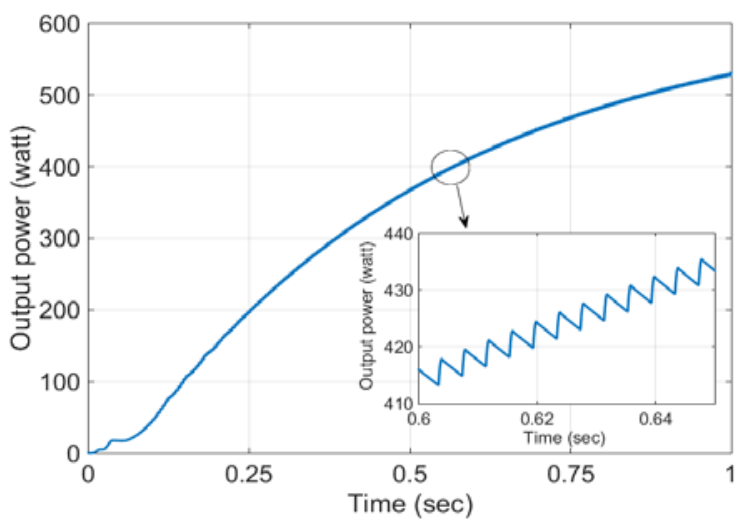

Figure 10a. Po for PV system buck-boost converter with PWM

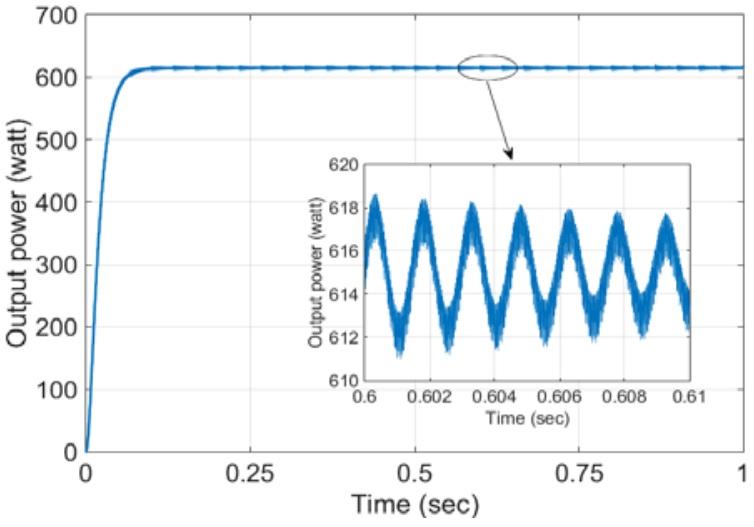

Figure 10b. Po for PV system boost converter with MPPT

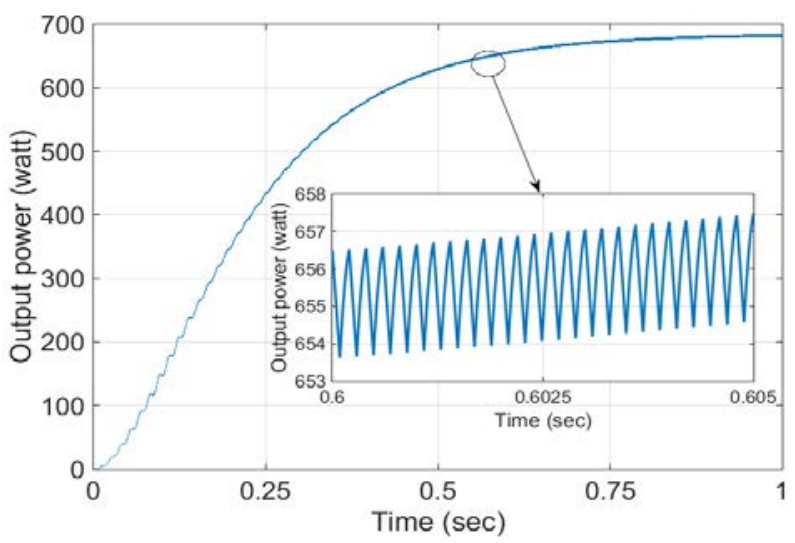

Figure 10c. Io\&Iin for PV system buck-boost converter with MPPT

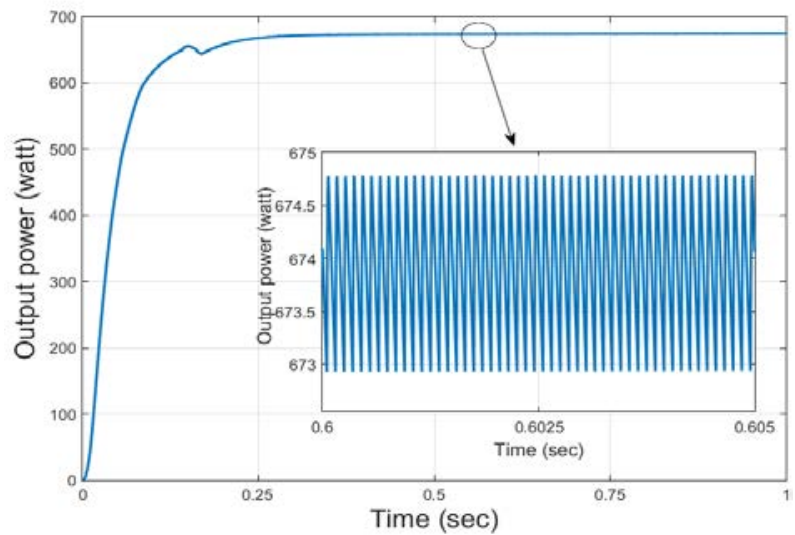

Figure 10d. Po for PV system buck-boost converter with PID - MPPT 
Table 2. Output results of PV system for different models

\begin{tabular}{|c|c|c|c|}
\hline $\begin{array}{c}\text { Results } \\
\text { Model }\end{array}$ & $\begin{array}{c}\text { Po } \\
\text { (watt) }\end{array}$ & $\begin{array}{c}\Delta \text { Po } \\
\text { Ripple } \\
\text { (watt) }\end{array}$ & $\begin{array}{c}\text { Vo } \\
\text { (volt) }\end{array}$ \\
\hline $\begin{array}{c}\text { PV system usage buck-boost } \\
\text { converter based on MPPT with PID }\end{array}$ & 690 & 1.7 & 360 \\
\hline $\begin{array}{c}\text { PV system usage buck-boost } \\
\text { converter based on MPPT }\end{array}$ & 675 & 3.8 & 350 \\
\hline $\begin{array}{c}\text { PV system usage boost converter } \\
\text { based on MPPT }\end{array}$ & 620 & 7.5 & 325 \\
\hline $\begin{array}{c}\text { PV system usage boost converter } \\
\text { based on PWM. }\end{array}$ & 535 & 20.2 & 315 \\
\hline
\end{tabular}

\section{Conclusions}

Converter and MPPT system based on incremental conductance algorithm conclude that the MPPT controller deliver maximum power possible by using proposed model and give adjustment duty cycle of the DC-DC converter at any change in the irradiance.

In This paper the performance of different models for PV system using MATLAB/Simulink are implemented. The maximum power is obtained using proposed model method. It is observed that the characteristics obtained based on this method is closest to the theoretical and simulations. Also from this proposed model, maximum values of voltage, maximum value of current and maximum value of power are developed and have a low ripple compared with the three other models. Thus the proposed simulation model of DC-DC converter with PID-MPPT algorithm can be used as a reference for presentation of actual system.

\section{REFERENCES}

[1] Irtaza M.Sayed, Kaamran Raahemifar, "Model Predictive Control of [1]. Irtaza M.Sayed, Kaamran Raahemifar, "Model Predictive Control of Three Phase Inverter for PV Systems ${ }^{\text {ee }}$. Intera national Journal of Electrical, Computer, Energetic, Electronic and Communication Engineering IEEE Trans. Energy Conversion, vol. 9, no. 10, pp. 1126-1131, 2015.

[2] I. H. Altas, A. M. Sharaf, “A Photovoltic Array Simulation Model for Matlab-Simulation GUI Environment”. IEEE International Conference on Clean Electrical Power. pp. 341-345, May. 2007.

[3] Chen Qi, Zhu Ming, "Photovoltic Module Simulink Model for a Stand-alone PV Systems". International Conference on Applied Physics and Industrial Engineerig, pp. 94-100. February. 2012.

[4] Chouki Balakishan, N. Sandeep, M. V. Aware, "Design and Implementation of Three-Level DC-DC Converter with Golden Section Search Based MPPT for the Photovoltic Applications”. Hindawi Publication Corporation Advances in Power Electronics, vol. 2015, pp. 1-9, 2015.

[5] Gudimetla Ramesh, Kari Vasavi, S. Lakshmi Sirisha,
"Photovoltic Cell Fed 3-Phase Induction Motor Using MPPT Technique". International Journal of Power Electronics and Drive System (IJPEDS), Vol. 5, No2, pp. 203-210, October 2014. (2008) 453 - 464.

[6] N. A. Kamarzaman, C. W. Tan,” A comprehensive review of maximum power point tracking algorithms for photovoltaic systems,” Renew Sustainable Energy Rev, Vol 37, pp. 585-598, Sept.2014.

[7] M. H. Moradi, and A. R. Reisi, "A Hybrid Maximum Power Point Tracking Method For Photovoltaic Systems, "Journal of Solar Energy, Vol. 85, No.11, pp. 2965-2976, November 2011.

[8] MD.SAFIA, T V V PAVAN KUMAR, "Design and Simulation of Grid Connected PV system Using Multilevel Inverters". International Journal of Electrical and Electronics Engineering (IJEEE), vol 4, Issue 2, pp. 52-59, 2013.

[9] Zaghba Layachi, A, Borni, A .Bouchakour, N.Terki, “ Buck-Boost Converter System Modeling and Incremental Inductance Algorithm for Photovolyic System via MATLAB/Simulink". The 2nd International seminar on New and Renewable Energies, pp. 1-6, Algeria, October 2014.

[10] A. Bouchakour, L. Zaghba, M. Brahami, A. Borni, "Study of a Photovoltic System Using MPPT Buck-Boos Converter”. International Journal of Material, Mechanics, Manufacturing, vol.3, No.1, pp. 65-68, February 2015.

[11] Lijun Qin, Xiao Lu, “Matlab/Simulink-Baswd Research on Maximum Power Point Tracking of Photovoltic Generation”. ". International Conference on Applied Physics and Industrial Engineerig, pp. 10-18, February. 2012.

[12] M. T. Ullah, M. H. Uddin, M. Quamruzzaman, "Performance analysis of DC/DC Boost Converter with Maximum Power Point Tracking for Grid connected Photovoltic Systems”. International Conference on Physics sustainable Development \& Technology (ICPSDT-2015), PP. 133-139, August 2015.

[13] Syed Enam Reza, A. S. M. Kaikobad, Abd-AI- Fattah-Ibne Mahabub, Md. Mehadi Hassan Nahid, Arif Ahammad, Md. lakaria Rahimi, "A study on the Reactive Power Control Mechanism of Current source Boost Inverter for Photovoltaic Power System". IEEE 2nd Int'l Conf on Electrical Engineering and Information \& Communication Technology (ICEEICT), 21-23 May 2015.

[14] K. Mahsa Ghapandar, M. Maziar, B. Subhashish, "Variable interleaving technique for photovoltaic cascaded DC-DC converters". 40th Annual Conference of the IEEE Industrial Electronics Society, IECON 2014, pp. 5612-5617,2014.

[15] Lunation of new FLC controller based MPPT for a DC to DC buck-boost zeta converter" WSEAS TRANSACTIONS on POWER SYSTEMS, volume 11, pp. 27-34, 2016.

[16] Gomathi B Sivakami P, "An Incremental Conductance Algorithm based Solar Maximum Power Point Tracking System". International Journal of Electrical Engineering, volume 9 Number 1, pp. 15-24, 2014.

[17] Nur Atharah Kamarzamana, Chee Wei Tanb, "A comprehensive review of maximum power point tracking algorithms for photovoltaic systems". Renewable and 
Sustainable Energy Reviews, volume 37, pp. 585-598, 2014.

[18] [18] Unal Yilmaz, AliKircay SelimBorekci, "PV system fuzzy logic MPPT method and PI control as a charge controller". Renewable and Sustainable Energy Reviews, Volume 81, Part 1, January 2018, Pages 994-1001, 2018.

[19] [19] Sukarno Budi Utomo, Iwan Setiawan, Berkah Fajar, S. H.Winoto, , "Design and development of maximum power point tracking (MPPT) for 100 watt solar panel base on buck boost converter". AIP Conference Proceedings 2173, 02001 (2019), pp. November 2019 